\title{
Common Carriers Under the Communications Act
}

When it enacted the Communications Act of 1934, ${ }^{1}$ Congress borrowed the concept of common carriage from the transportation field to describe and regulate companies providing public communications services. ${ }^{2}$ In the half-century since then, the Federal Communications Commission ("FCC") has added to the body of precedent interpreting the term "common carrier"s a number of decisions that discuss the scope of the term in the communications context. Recently, the significance of the concept has been brought to the fore by an FCC decision deregulating the computer enhancement of communication services, ${ }^{4}$ and by a tentative decision that would greatly restrict the FCC's common carrier jurisdiction." Surprisingly, however, there have as yet been no comprehensive analyses of the definition of a communications common carrier. ${ }^{6}$ This comment seeks to provide such an analysis. After reviewing the Commission's jurisprudence in this area, the comment suggests that an elemental approach to the definition will lead to more effective decision making in the future.

1 Ch. 652, 48 Stat. 1064 (codified at 47 U.S.C. $\$ \$ 151-609$ (1976)).

2 See FCC v. Sanders Bros. Radio Station, 309 U.S. 470, 474 (1940) (dictum) (communications common carriers are regulated "in analogy to the regulation of rail and other carriers").

3 For a general discussion of the term, see L. Gonton, The Concept of the Common Carrier in Anglo-American Law (1971).

- Second Computer Inquiry, 77 F.C.C.2d 384 (1980).

- Competitive Carrier Rulemaking, No. 79-252 (F.C.C. Jan. 16, 1981) (Further Notice of Proposed Rulemaking).

- An arguable exception is Annot., 46 A.L.R. Fed. 626 (1980). Although the discussion there is useful, it is limited to summaries of the cases and does not employ the elemental analysis used here. Several articles discuss whether individual services constitute common carriage. See, e.g., Berman, CATV Leased-Access Channels and the FCC: The Intractable Jurisdiction Question, 51 Notre Dame Law. 145, 179-81 (1975); O'Riordan, An Examination of the Application of Common Carrier Regulation to Entities Providing New Telecommunications Services, 29 Case W.L. Rzv. 577 (1979); Shapiro, Epstein \& Cass, Cable Satellite Networks: Structures and Problems, 24 Cath. U.L. REv. 692, 708-13 (1975); Verrill, CATV's Emerging Role: Cablecaster or Common Carrier?, 34 Law \& ContzmP. Prob. 586, 607-09 (1969); Comment, Computer Services and the Federal Regulation of Communications, 116 U. PA. L. REv. 328, 337-40 (1967). 


\section{BACKGROUND}

\section{A. The Significance of Common Carrier Status}

The Communications Act contains two distinct schemes of regulation: ${ }^{7}$ Title II of the Act ${ }^{8}$ deals with common carriers of communication services (both by wire and radio), while Title $\mathrm{III}^{9}$ governs the use of the radio spectrum, regardless of the nature of the service or use. ${ }^{10}$ Classification of a firm as a common carrier vel non may therefore be relevant under both schemes. ${ }^{11}$

Title II requires common carriers to furnish service at reasonable and nondiscriminatory rates, to file tariff schedules with the FCC, to employ agency-prescribed accounting procedures and depreciation rates, to obtain FCC approval for the addition or discontinuance of services, to expand services if ordered to do so by the FCC, and to submit merger and acquisition plans to the Commission for approval. Thus, because of the restrictions imposed on the use of certain radio frequencies and because of the perceived undesirability of being subjected to the pervasive scheme of regulation in Title II, the issue of who is a common carrier often arises

I It is convenient to refer to the FCC's authority under these two schemes as its "Title II" and "Title III" jurisdictions. A third basis of jurisdiction, the FCC's "ancillary" or "Title I" jurisdiction, has been recognized as well. Title I, Communications Act of $1934 \$ \S 1-5,47$ U.S.C. $\$ \S 151-155$ (1976), contains the general provisions of the Act, including section 2(a), 47 U.S.C. § 152(a) (1976), which describes the FCC's jurisdiction comprehensively as "all interstate and foreign communication by wire or radio and . . transmission of energy by radio." Despite the lack of substantive provisions in Title $I$, the courts have recognized the power of the FCC to regulate entities that fall within the general scope of that title, even though the entity does not fall within the more specific jurisdictions prescribed in the substantive Titles II or III. See, e.g., United States v. Southwestern Cable Co., 392 U.S. 157 (1968) (cable television). Title I jurisdiction enables the FCC to regulate such entities to the extent necessary to effectuate the policies contained in Titles II and III. See id. at 178 (concerning Title III).

B Communications Act of $1934 \S \S 201-223,47$ U.S.C. $\S \S 201-223$ (1976).

- Id. §§ 309-399.

10 Title III applies to both broadcast and nonbroadcast use of the spectrum. It empowers the FCC to classify radio stations and prescribe the nature of the service to be rendered by each such class. Id. $\S 303(\mathrm{a})$, (b). Pursuant to this authority, the Commission has declared that certain classes of stations may be operated only on a non-common carrier basis. 47 C.F.R. § 90.415(b) (1979).

11 Jurisdictions under Titles II and III are not mutually exclusive; a firm can be regulated under both at the same time. National Ass'n of Regulatory Util. Comm'rs v. FCC (NARUC I), 525 F.2d 630, 644-45 (D.C. Cir.), cert. denied, 425 U.S. 992 (1976) [hereinafter cited as NARUC I]. For example, radio common carriers (which offer such services as paging, dispatching, and radio telephones) are licensed under Title III and regulated under Title II. 
when the FCC attempts to impose such a classification on an unwilling firm.

In some instances, however, the issue arises because a firm seeks to gain or retain common carrier classification. First, classification as a common carrier results in incidental protection from certain liabilities. The Copyright Act of 1976 exempts common carriers from liability for transmission of certain copyrighted works. ${ }^{12}$ Similarly, a common carrier enjoys a qualified immunity from liability for the transmission of a defamatory message. ${ }^{13}$ Second, an established common carrier may find it desirable to retain the FCC's regulation of itself or of another firm because of the economic protection such regulation can provide. For instance, a reasonable rate of return on capital is guaranteed to regulated businesses; it may be the explicit policy of the FCC to reduce competition in that industry; ${ }^{14}$ and an established firm may find that regulation of an industry gives it a competitive edge over potential entrants because regulation creates entry barriers. ${ }^{18}$ Third, a communications firm might wish to be classified as a common carrier in order to avoid the jurisdiction of other regulatory authorities. For example, a nationwide common carrier might desire federal regulation because of its preemptive effect on state regulation, ${ }^{16}$ thereby ensuring at least uniformity of regulation. Finally, because section 2(b) of the Act declares that a common carrier engaged in interstate commerce solely by virtue of its physical connection with another common carrier is subject to only limited regulation by the $\mathrm{FCC},{ }^{17}$ a local communications firm might wish to be classified as a common carrier in order to avoid federal regulation.

1217 U.S.C. $\$ 111(a)(3)$ (Supp. I 1977).

1s See O'brien v. Western Union Tel. Co., 113 F.2d 539, 540-43 (1st Cir. 1940); Berman, supra note 6 , at 178 \& n.197.

14 See, e.g., Note, The Use of Section 214 of the Communications Act of 1934 to Control Shifts in Corporate Control Over Common Carriers, 29 CATH. U.L. REv. 891, 901-02 (1980) (sections 221 and 222 of the Act were enacted to allow the FCC to immunize carrier mergers from the antitrust laws). The FCC might choose to supress competition either because the field involves a natural monopoly or because competition would tend to be ruinous. See text and notes at notes $47,170-174$ infra.

15 Resale \& Shared Use of Common Servs. \& Facilities, 60 F.C.C.2d 261, 339 (1976) (Robinson, Comm'r, concurring in part and dissenting in part) ("all who labor in regulated vineyards know . . . that regulation is . . a tool by which regulated carriers protect themselves against competition").

16 See Western Union Tel. Co. v. State, 207 Ga. 675, 63 S.E.2d 878 (1951).

17 Communications Act of 1934 \&(b), 47 U.S.C. $\S 152(b)$ (1976). Section 2(b) provides that such carriers are in large part to be regulated by the states exclusively. 


\section{B. The Statutory Definition of Common Carriage}

The Communications Act defines a common carrier as "any person engaged as a common carrier for hire, in interstate or foreign communication by wire or radio or interstate or foreign radio transmission of energy, . . . but a person engaged in radio broadcasting shall not, insofar as such person is so engaged, be deemed a common carrier."18 This definition has been deprecated as "circular"19 and "not meaningful."20 Its supposed inadequacies have been used to justify reliance on the common law of common carriage. ${ }^{21}$ Although it is proper to rely on the common law, for the legislative history instructs that the term "common carrier" is to be applied in its "ordinary sense," 22 this is no reason to ignore the statutory definition ${ }^{23}$ and to rely solely on the panorama of common law precedents. Such an approach leads to inadequate analysis because it fails to examine every element of the definition or tends to deal with the elements in an oblique manner, thereby making it difficult to determine whether any given element has been satisfied.

The Act's definition of common carriage should be regarded as a valuable analytical tool, because it serves to introduce the essential elements of the concept: common; carrier; engaged in communication; for hire; but not broadcasting. A further narrowing of the definition, not mentioned in the Act but well grounded in case law $^{24}$ and legislative history, ${ }^{25}$ is the exclusion of press associations such as United Press International and Associated Press. As each of these elements must be satisfied before a firm can be classified as a communications common carrier, it is convenient to employ them as an organizing scheme for a discussion of relevant FCC and judicial precedents.

18 Id. § 3(h), 47 U.S.C. § 153(h) (1976).

18 FCC v. Midwest Video Corp., 440 U.S. 689, 701 n.10 (1979).

${ }^{20}$ Competitive Carrier Rulemaking, No. 79-252, I 54b (F.C.C. Jan. 16, 1981).

21 Competitive Carrier Rulemaking, 77 F.C.C.2d 309, 363 (1979). See NARUC I, 525 F.2d 630, 640 (D.C. Cir.), cert. denied, 425 U.S. 992 (1976).

${ }^{22}$ H.R. Conf. REP. No. 1918, 73d Cong., 2d Sess. 46 (1934).

${ }^{23}$ The FCC's recent tentative decision proposes to do just that, however. In the Commission's opinion, common carriage is not an idea "existing in nature"; accordingly, it proposes to classify communication firms as common carriers when it decides that the Title II requirements "are useful or necessary." Thus, "common carrier" would describe entities that the FCC chooses to regulate- "no more and no less." Competitive Carrier Rulemaking, No. 79-252, I 54c (F.C.C. Jan. 16, 1981).

24 See text and notes at notes 113-116 infra.

${ }^{25}$ H.R. Conp. REP. No. 1918, 73d Cong., 2d Sess. 46 (1934); H.R. REP. No. 1850, 73d Cong., 2d Sess. 4 (1934). 


\section{The Essential Elements of Common Carriage}

\section{A. Common}

1. The Principles. Perhaps the most frequently recited prerequisite to imposing common carrier status is that the carrier must be one that serves the public indiscriminately. It is in this sense that a common carrier is "common," because it undertakes to serve the public at large, holding out its services to all who may choose to use them. A carrier whose holding out is not sufficiently public to meet this standard is a private carrier. ${ }^{26}$

The size of a firm's operation is not determinative of its status as a common carrier, nor is it relevant that its services may be specialized and therefore of interest only to a small segment of the public. ${ }^{27}$ Rather, the manner and terms by which companies approach and deal with customers determines this element of the common carrier definition. ${ }^{28}$ Thus FCC decisions that appear inconsistent on their face are reconcilable because of the complex nature of such an inquiry. For example, the Commission has held in two decisions that applicants are common carriers even though each had only one customer at the time, ${ }^{2 \theta}$ while another decision has viewed a service offered only to NASA to be private carriage on the grounds that it was designed to serve the needs of only one customer. ${ }^{30}$ The relevant difference was that in the first two cases the carriers intended to solicit additional customers and expand their services accordingly in the future, while, in the latter case, the carrier intended to serve only one customer.

The FCC and the courts have not been entirely faithful to these principles, however. In three decisions, the Commission has relied on the specialized nature of the services offered in holding or (1976).

${ }^{28}$ See generally NARUC I, 525 F.2d 630, 640-43 (D.C. Cir.), cert. denied, 425 U.S. 992

${ }^{27}$ Id. at 641-44. For example, communication services offered only to theater owners, Theatre Television Serv., 9 Rad. REg. (P \& F) 1528, 1538 (F.C.C. 1953), members of the stock exchanges, Western Union Tel. Co. Sicom Serv., 11 F.C.C.2d 1, 9 (1967), the television broadcasting industry, Teleprompter Corp., 13 RAD. REG. (P \& F) 111 (FCC Public Notice No. 25210, 1955), and the United States Postal Service, Graphnet Syss., Inc., 73 F.C.C.2d 283, 298 (1979), have all been viewed as constituting common carriage.

${ }^{28}$ NARUC I, 525 F.2d 630, 641-42 (D.C. Cir.), cert. denied, 425 U.S. 992 (1976). “[A] carrier will not be a common carrier where its practice is to make individualized decisions, in particular cases, whether and on what terms to deal." Id. at 641.

${ }^{29}$ Southern Satellite Syss., Inc., 62 F.C.C.2d 153, 160 (1976); Tower Communications Syss. Corp., 59 F.C.C.2d 130, 131 (1976).

so National Aeronautics \& Space Admin., 61 F.C.C.2d 56, 58 (1976). 
suggesting that various mobile radio services are not common carriage because the class of potential customers was limited to radio licensees and because the facilities provided could be used only for specific purposes. ${ }^{31}$ The court in National Association of Regulatory Utility Commissioners v. FCC (NARUC I) ${ }^{32}$ corrected the approach taken in these decisions when it held a new category of mobile radio licensees to be private carriage. The court rejected as rationales the possibility that the service "may be of practical use to only a fraction of the population" or the possibility that subscribers may be limited to certain radio licensees; instead, it relied on predictions that the clientele of the new operators would be stable, that services would be provided under long-term contracts, and that operators had reason to make highly individualized selections of customers because of concern about the compatability of the customers' methods of operation with the overall system. ${ }^{33}$ In applying these predictions to the entire industry, however, the court ignored the necessarily individual nature of the inquiry by failing to acknowledge (although the case did not force it to decide) that some operators in the new service might choose to offer services in an entirely open manner. ${ }^{34}$

A more successful application of these principles is found in a series of decisions treating communication services as private carriage if they are shared on a nonprofit basis. ${ }^{35}$ This rule employs the reasonable presumption that such firms do not have an incentive to solicit the public's business at large, and its controlling indicium of private carriage is not the nature of the services but the manner and terms of dealing with users. More importantly, the presumption is not absolute; it will be reexamined if the carrier's activities indicate that communication services are being held out indiscriminately to the public. ${ }^{38}$ This approach to the holding out element is desirable because it allows a firm to organize its affairs so as to fall predictably inside or outside of the scope of the defini-

${ }^{31}$ Alyeska Pipeline Serv. Co., 59 F.C.C.2d 281, 284 (1976); Preston Trucking Co., 31 F.C.C.2d 366, 372 (1971); Multiple Licensing-Safety \& Special Radio Servs., 24 F.C.C.2d 510,519 n.2 (1970).

32525 F.2d 630 (D.C. Cir.), cert. denied, 425 U.S. 992 (1976).

${ }^{33}$ Id. at 642,644 .

34 The court did concede that its prediction of methods of operation might be mistaken. It did so, however, by suggesting only that its prediction might prove incorrect for the industry as a whole, rather than that it might be correct as to some operators and mistaken as to others. Id. at 644 .

ss See text and notes at notes 101-104 infra.

ss AT\&T v. FCC, 572 F.2d 17, 26-27 (2d Cir.), cert. denied, 439 U.S. 875 (1978). 
tion, while it preserves sufficient flexibility for the FCC to detect common carrier activities hiding behind a nonprofit facade.

2. Doctrinal Weaknesses. There are two important theoretical concerns about the holding out criterion. The first is the "dizzying circularity" that it creates. ${ }^{37}$ One result of assuming common carrier status is the duty to hold out services to all customers on a nondiscriminatory basis. ${ }^{38}$ There is a paradox involved here, in that the holding out is viewed as both a necessary precondition and a necessary result of common carrier regulation. ${ }^{38}$

The second fundamental concern is whether the holding out criterion is relevant to the imposition of common carrier status. Generally, such a status has been associated with two distinct sets of duties: one is strict liability for destruction of carried goods, and the other is the obligation to provide services at reasonable prices. ${ }^{10}$ Originally, however, the requirement of a public undertaking or holding out was developed only in the context of the first set of duties. ${ }^{41}$ This prerequisite to common carrier status was thought to have both procedural and substantive relevance. Procedurally, the rules of pleading at common law focused on a defendant's undertaking; substantively, it was thought that only those who held out their services to the public at large voluntarily assumed the higher standard of care.42 Because one's undertaking arguably is relevant only to the measure of tort liability, and strict liability is not imposed on communications common carriers, the function served by the holding out requirement in a determination whether a communications firm should be classified as a common carrier is

37 Reply Comments of IBM Corp. at 11, Competitive Carrier Rulemaking, No. 79-252 (F.C.C. Apr. 4, 1980) (on file with The University of Chicago Law Review); see id. at 7.

ss See Communications Act of 1934 \$201(a), 47 U.S.C. § 201(a) (1976). See also id. $\S 201$ (b) (requiring that the classifications be just and reasonable).

so As one scholar of the law of common carriage explains, this leads to circular reasoning:

one may reach the definition that "he is a common carrier who is a common carrier," for he who holds himself out to the general public is a common carrier, and he who is a common carrier must hold himself out to carry for anybody who chooses to use him.

L. Gorton, supra note 3, at 11. For an even more tautological explanation, see 1 R. Hutchinson, A Trbatise on the LaW of Carrisrs 59 (3d ed. 1906).

40 See L. Gorton, supra note 3, at 42.

1 See NARUC I, 525 F.2d 630, 640 (D.C. Cir.), cert. denied, 425 U.S. 992 (1976).

42 See Comments of IBM Corp. at 8-9, Competitive Carrier Rulemaking, No. 79-252 (F.C.C. Mar. 14, 1980) [hereinafter cited as IBM Comments] (on file with The University of Chicago Law Review); Comments of the National Telecommunications \& Information Admin. at 22, 35, Competitive Carrier Rulemaking, No. 79-252 (F.C.C. Mar. 14, 1980) [hereinafter cited as NTIA Comments] (on file with The University of Chicago Law Review). 
not readily apparent. The FCC has in fact proposed to eliminate the requirement, relying on these doctrinal weaknesses. ${ }^{43}$

These objections to the holding out requirement can be overcome. First, this element of the definition of common carriage has the force of congressional fiat. The legislative history of the Communications Act states that the term "common carrier" is to be applied in its "ordinary sense";" the uniform understanding then, as now, was that "the dominant and controlling factor in determining the status of one as a common carrier is his . . . holding out."45 As a matter of statutory construction, then, the requirement of a holding out cannot simply be discarded; rather, it must be interpreted in a meaningful way. This is possible despite the two concerns noted above.

The circularity can be logically resolved, or at least pragmatically tolerated, if the reasons for imposing both the precondition and the resulting duty of holding out are understood. First, the duty "to furnish . . . communication service upon reasonable request"46 is necessary because of the natural monopoly enjoyed by many common carriers, such as telephone and telegraph companies. ${ }^{47}$ If a monopolistic carrier could assume private carrier status

${ }^{13}$ Competitive Carrier Rulemaking, No. 79-252, ปโ 61-62, App. B กิ 9, 12, $41-42$ (F.C.C. Jan. 16, 1981).

14 See text and note at note 22 supra.

459 AM. JUR. 2D Carriers § 4, at 43 (1964); 9 AM. Jur. Carriers § 4, at 431 (1937); see, e.g., The Propeller Niagara, 62 U.S. (21 How.) 7, 22 (1858); L. Gorton, supra note 3, at 79, 80-81; 1 R. Hutchinson, supra note 39, at 44. See also 10 C.J.S. Carriers $\$ 10$, at 41 (1917).

${ }^{4}$ Communications Act of $1934 \S 201$ (a), 47 U.S.C. $\S 201$ (a) (1976).

47 Cf. General Tel. Co. v. United States, 449 F.2d 846, 851, 856, 859 (5th Cir. 1971) (because telephone companies have monopoly control over pole and conduit space, it is rational to require them to offer space to CATV operators). Such carriers are allowed to enjoy monopoly status because of the natural monopoly condition that characterizes much of the industry. For example, it would be inefficient to have two telephone lines serving the same area where one would be sufficient. See 2 A. Kahn, The Economics of Regulation: PrinciPLES AND INSTITUTIONS 2, 34, 122, 227-28 (1971). Where such economies of scale exist, it is in the public interest to exclude competitors. See FCC v. RCA Communications, Inc., 346 U.S. 86, 93 (1953) (dictum) ("Congress may have considered the possible inconvenience to the public of duplicate facilities-as would clearly be the case with telephones- . . to make more than one enterprise economically or socially undesirable") (reversing an FCC decision to allow a second company to compete with $\mathrm{RCA}$ in international radio communication between certain points). See also Posner, Natural Monopoly and Its Regulation, 21 Stan. L. REv. 548, 548 (1969):

If the entire demand within a relevant market can be satisfied at lowest cost by one firm rather than by two or more, the market is a natural monopoly . . . . If such a market contains more than one firm, ... [provision of services] will . . . consume more resources than necessary ... [and therefore] produce[ ] inefficient results. Competition is thus not a viable regulatory mechanism under conditions of natural 
by adopting a business policy of individual contracting, it would be able to remove itself from rate regulation and charge excessive rates. It is sensible, therefore, to require carriers that have entered the regulated field of common carriage by a sufficient holding out to continue to hold out their services so that the FCC may retain its jurisdiction over them. ${ }^{48}$

A second justification for the circularity is that it serves to define the precise scope of the duty to serve. The Communications Act imposes a duty "to furnish . . . communication service upon reasonable request," 49 but does not indicate what is "reasonable." One must look to the common law: "Generally, the duty to offer service extends as far as but no further than the company's undertaking ....." "Roasonable," therefore, means "to the extent of one's holding out." ${ }^{\prime 1}$ This definition is sensible because it would be unfair, under normal circumstances, ${ }^{52}$ to require a common carrier to offer more services than it has undertaken to provide, ${ }^{53}$ or to

monopoly.

ts See Note, The Duty of a Public Utility to Render Adequate Service: Its Scope and Enforcement, 62 CoLuM. L. REv. 312, 315 (1962) ("Once imposed, the duty to serve can not be extinguished by the unilateral action of the utility. Under any other rule, a segment of the public that has relied on a virtual monopoly to provide vital services could be irretrievably deprived of them at the whim of the utility." (footnote omitted)).

4 Communications Act of $1934 \$ 201$ (a), 47 U.S.C. $\$ 201$ (a) (1976).

so Note, supra note 48, at 314 (footnote omitted); accord, e.g., State ex rel. Webster v. Nebraska Tel. Co., 22 N.W. 237, 238-39 (Neb. 1885) (telephone company may not meet its service obligation to plaintiff simply by offering him telephone service through a public telephone station, because the company has undertaken to supply individual telephones to each member of the public).

s1 See Ward v. Northern Ohio Tel. Co., 300 F.2d 816 (6th Cir.) (telephone company not allowed to refuse service to radio station that had patronized it in the past), cert. denied, 371 U.S. 820 (1962). Note that there have been few actions brought for refusal of service, so the meaning of "reasonable" in this context is largely uncharted law.

${ }^{62}$ The exceptional case is provided for in Communications Act of 1934 \& 214(d), 47 U.S.C. $\$ 214$ (d) (1976), which gives the FCC the power to require a common carrier to expand its services if the "public convenience and necessity" so demands. This power does not undermine the analysis in text, because it is a type of duty distinctly different from the duty to serve upon reasonable request. Procedurally, only the latter duty is enforceable through a private action brought in the district courts, see id. $\$ \S 206,207$, while the former duty arises only after a formal hearing by the FCC, see id. $\S 214(\mathrm{~d})$. Substantively, there is a marked difference between the two: the private right is governed by a reasonableness standard while the public right is governed by the narrower public necessity standard. It is argued here that a carrier's holding out is relevant only to the first type of duty to serve.

ss For example, a carrier may turn away business because its capacity is inadequate or because the business is not the type normally accepted, even though the carrier is a common carrier. NARUC I, 525 F.2d 630, 641 (D.C. Cir.), cert. denied, 425 U.S. 992 (1976); cf. Eastex Tel. Coop., Inc., 45 F.C.C.2d 464, 469 (1974) (a local, intrastate telephone company was justified in serving only affluent subdivisions because it had honored all requests for service by residents within a reasonable proximity to its trunk lines and was free under Texas law 
impose any duty to serve if the carrier has never undertaken a public offering.

Third, the holding out requirement and the holding out responsibility are not necessarily tautological for every carrier, because the offering necessary to trigger common carrier regulation may be different from the offering a common carrier must continue to provide under that regulation. For example, a common carrier may be required to expand its service into new areas to meet public need. ${ }^{54}$ Similarly, an offering of services to all comers except one racial or ethnic group would be sufficiently public to trigger a duty to serve all comers, including the group excluded in the offering.

The strongest objection to the circularity is that the confusion it generates may result in imposition on a firm of a duty to serve indiscriminately before the firm ever voluntarily brings itself within the Communications Act's common carrier jurisdiction. The FCC and one federal court apparently have condoned such an operation. In its Resale \& Shared Use decision, ${ }^{\mathrm{sb}}$ the FCC, in ruling that resellers of common carrier services are themselves common carriers, reasoned that they must be so because the Commission was not going to "permit resellers to operate in a discriminatory fashion." Similarly, the court in NARUC $I$, in holding certain mobile radio operators not to be common carriers, observed that although "the Commission could have treated [them] as common carriers by ... requir[ing them] to serve all potential customers indifferently, thus making them common carriers," misguided. Under Title II, the FCC has authority to impose service requirements only on a firm that is already a common carrier; thus it may not create a common carrier by imposing such requirements. This observation must be tempered if the FCC has another basis for jurisdiction over a potential common carrier besides Title II of the Act; in that case, it might be able to use that jurisdiction to "force" a company to become a common carrier. ${ }^{60}$ If a proper

to choose its areas of service).

s4 See note 52 supra.

ss Resale \& Shared Use of Common Servs., 60 F.C.C.2d 261 (1976).

s8 Id. at 308.

${ }^{37}$ NARUC I, 525 F.2d 630, 644 n.76 (D.C. Cir.), cert. denied, 425 U.S. 992 (1976).

ss Id. at 642 .

s2 Communications Act of 1934 §§ 201(a), 202(a), 47 U.S.C. $\S \S 201(a), 202(a)$ (1976).

so For instance, if a company provides services over the airwaves, it must obtain a license to operate. The FCC could argue that it has the authority to condition the grant of 
jurisdictional basis is identified before imposition of a common carrier duty to serve, the circularity inherent in the holding out requirement is not fatal.

Despite some superficial appeal because the notion of "undertaking" often arises in the context of tort liability, ${ }^{61}$ the argument for the second fundamental concern-that a holding out may be irrelevant to communications common carriers because they are not saddled with the strict liability of a transportation common carrier-is not persuasive either. First, the extent of a carrier's undertaking is clearly relevant to the extent of service duties imposed. ${ }^{62}$ Second, the Supreme Court has explicitly rejected this reasoning in another context. Washington ex rel. Stimson Lumber Co. v. Kuykendall ${ }^{63}$ asked whether operators of logging towboats were to be considered common carriers for purposes of a state statute that imposed rate regulation. The Court held them to be common carriers because they "held themselves out as engaged in the business of common carriers," rejecting as irrelevant and unpersuasive the fact that $\log$ towers were not held to the strict liability of common carriers. ${ }^{64}$

\section{B. Carrier}

The second element of the definition of a common carrier concerns the degree of control a company must maintain over the transmission of communications before it properly can be termed a

such a license on the company's assumption of a common carrier's status and duties. See Communications Act of 1934 §§ 303(f), (r), 308(b), 47 U.S.C. $\S \S 303(f),(r), 308(b)$ (1976). With regard to wire services, jurisdiction to impose common carrier duties arguably exists because of the FCC's "ancillary" or "Title I" jurisdiction, see note 7 supra. Second Computer Inquiry, 77 F.C.C.2d 384, 432 (1980).

or Note that the relevance of a firm's holding out to its tort liability is subject to dispute:

[Common carriers' duty to carry] goods upon a contract of insurance . . . [arises] not because they hold themselves out to carry for all persons indifferently; if that were all, there would be no ground for the policy; it would be without reason; many other persons hold themselves out to act in their trade or business for all persons indifferently who will employ them, and the policy in question is not applied to such trades . . . . Nugent v. Smith, 1 C.P.D. 19, 27 (1875).

${ }^{62}$ See text and notes at notes 49-53 supra; cf. NARUC I, 525 F.2d 630, 641 (D.C. Cir.) (the carrier's holding out is critical whether the common carrier "concept is invoked to support strict tort liability or as a justifying basis for [rate] regulation"), cert. denied, 425 U.S. 992 (1976).

os 275 U.S. 207 (1927).

or Id. at 211. 
"carrier." At common law, the mere furnishing of the means of transportation was not considered common carriage because, with the customer operating the vehicle, the furnishing firm performs no act of carriage. ${ }^{66}$ This principle is applied by analogy in the communications context, both by implication from the term "carrier" and by the express provisions of the Act. Read together, subsections $3(\mathrm{a}),(\mathrm{b})$, (d), and (h) ${ }^{\mathrm{er}}$ say that a person must transmit radio or wire signals to be considered a common carrier. Thus the Commission has held that the mere offering of transmission equipment is not common carriage unless the person so offering is engaged in the "transmission" as well. ${ }^{68}$

Problems of application can arise, however, because the analogy from the transportation field is not precise. Basic telephone service, whereby the customer operates the transmitting equipment, indisputably is common carriage; this indicates that "transmission" or "carriage" involves only operation and maintenance of the lines. Where the "lines" are the airwaves and the customer continues to operate the transmitting equipment, the concept of transmission or carriage is stretched even further. Nevertheless, a mobile radio telephone service, for example, can be offered on a common carrier basis, ${ }^{69}$ despite the entrepreneur's negligible or nonexistent role in the actual transmission. The rationale is that the common carrier, as the licensee of the radio channel, is responsible to the FCC for supervising the channel's operation, and thus he has control over the "line" of transmission."

${ }^{65}$ See 9 AM. JUR. Carriers $\S 31$ (1937) ("It is elementary that one who performs no act of carriage cannot be regarded as a carrier").

${ }^{\text {Bs }}$ See 13 AM. Jur. 2D Carriers $\$ 18$ (1964).

a7 Communications Act of 1934 § $3(\mathrm{a})$, (b), (d), (h), 47 U.S.C. $\S 153(\mathrm{a})$, (b), (d), (h) (1976).

${ }^{88}$ See California Water \& Tel. Co., 64 F.C.C.2d 753, 758-59 (1977) (leasing of pole space to cable TV operators is not common carriage because "the pole owners are not themselves involved in cable television transmission at all"); Multiple Licensing-Safety \& Special Radio Servs., 24 F.C.C.2d 510, 518 (1970) ("it has never been seriously contended . . . that [mobile radio] equipment suppliers . . . are rendering a communications, let alone a common carrier communications, service").

${ }^{69}$ See NARUC I, 525 F.2d 630, 634 (D.C. Cir.), cert. denied, 425 U.S. 992 (1976).

so One can discern that this is the FCC's rationale from the following cases in which the Commission found mobile radio communication services not to be common carriage in part because the subscribers, rather than the offerors, were the licensees of the radio channels used. Preston Trucking Co., 31 F.C.C.2d 366, 366, 369, 372-73 (1971) (subscriber/licensee "will have dominion and control over the radio spectrum," id. at 369); Multiple Licensing-Safety \& Special Radio Servs., 24 F.C.C.2d 510, 519 n.2 (1970) (distinguishing between the private and common carrier status of mobile radio systems on the basis that, with the latter, "the carrier is the licensee and has the ultimate legal control of the radio facilities"). 
A controversial issue in this area is whether a reseller of communication services is a common carrier. Typically, a reseller subscribes to bulk communication services at discount rates offered by an underlying carrier such as AT\&T, and remarkets the services to consumers at a rate set between the bulk rate and that which the consumer would otherwise have to pay. ${ }^{71}$ The underlying carrier continues to operate the facilities; thus the reseller is engaged in a mere brokerage or arbitrage function. ${ }^{72}$ In other cases the reseller might also exercise varying degrees of control over the transmission by adding additional services to the basic transmission service. $^{73}$ In 1976, the FCC decided that all such resale activities are common carriage. ${ }^{74}$ Recently, however, it reconsidered and reversed this position. ${ }^{75}$

There are strong arguments on both sides of this issue. The case against regulation of resellers is based on a strict reading of the Act, which would indicate that resellers that perform no transmission functions whatsoever are not within the FCC's jurisdiction. ${ }^{78}$ A reading of the legislative history initially lends support to

See also Coleman Petroleum Eng'r Co., 24 F.C.C.2d 378, 379-81 (1970).

The principle discussed here is not that bare ownership of the line of communication is sufficient to constitute carriage, but rather that some responsibility, oversight, or control over the line is sufficient. Thus, if AT\&T were to build a complete telephone network, lines and all, and lease it to a customer who operated it without any assistance from AT\&T, AT\&T would not be involved in transmission but merely in the rental of equipment. $C f$. California Water \& Tel. Co., 64 F.C.C.2d 753, 758-59 (1977) (leasing of pole and conduit space by telephone companies to cable television operators does not constitute transmission, in part because the telephone companies have no "interest in insuring the proper transmission or delivery of the signals").

This principle, that control of the channel of communication is a prerequisite of common carriage, is also enforced even when the operator in question physically transmits the messages. For example, a dispatch or message-answering service is not considered common carriage unless the operator provides the facilities and is the licensee. See Multiple Licensing-Safety \& Special Radio Servs., 24 F.C.C.2d 510, 518 (1970). The rationale in such cases does not turn on lack of transmission but on the conclusion that such operators are "merely agents of the [subscriber/]licensee." Id.

71 See Resale \& Shared Use of Common Servs. \& Facilities, 60 F.C.C.2d 261, 271-72 (1976).

72 Id. at 272.

73 See id. at $272-74$.

24 Id. at 265.

${ }^{75}$ Competitive Carrier Rulemaking, No. 79-252, ๆा 120-134 (F.C.C. Jan. 16, 1981). The FCC's decision is based on the lack of market power, see note 88 infra, rather than the statutory or legislative history arguments that follow.

76 The requirement of transmission is underscored by section 214 , which requires carriers to obtain permission before expanding their services, but only if such expansion involves the acquisition, operation, or extension of, or transmission over, new lines. Communications Act of 1934 § 214, 47 U.S.C. § 214 (1976). 
this conclusion. The common carrier provisions for the most part follow those in the Interstate Commerce Act, ${ }^{77}$ and, under that statute, freight forwarders-who perform functions analogous to those of resellers ${ }^{78}$ - did not come within the jurisdiction of the Interstate Commerce Commission ("ICC") 79 until amendments were made in $1942^{80}$ and $1950 .^{81}$

On balance, though, the case for continued jurisdiction over resellers is more persuasive. First, the Act does not decisively require common carriers to transmit. A common carrier is defined as one who is "engaged ... in . . . communication";"82 communication is further defined as "transmission of . . . intelligence." common carrier, therefore, must merely be "engaged in transmission." Thus an entirely plausible reading of the Act, if "engaged" is taken to mean "in the business of," is that any offering of communication services to the public constitutes one a common carrier, even if another entity performs the actual transmission.

Second, a closer analysis of the legislative history confirms this reading of the Act. At common law, freight forwarders were considered to be common carriers, ${ }^{84}$ and the legislative history concerning the term "communications common carrier" can be read to refer to that source rather than to the Interstate Commerce Act. ${ }^{85}$ More-

It is noteworthy, though, that this provision has been construed quite liberally by the FCC in the past. See generally Note, supra note 14, at 896 . For example, the addition of multiplexing equipment (which allows several signals to travel simultaneously on the same channel by bandwidth division or time division) requires section 214 permission, Resale \& Shared Use of Common Servs. \& Facilities, 60 F.C.C.2d 261, 314 (1976), even though such equipment merely has the effect of increasing the efficiency of existing lines or channels, see J. Martin, Future Developments in Telecommunications 34 (1977).

${ }^{77} 49$ U.S.C. § 1(3) (1976) (superseded by 49 U.S.C. § 10102 (Supp. III 1979)); see S. REP. No. 781, 73d Cong., 2d Sess. 2 (1934).

${ }^{78}$ Freight forwarders aggregate small quantities of goods and tender them for shipment to a carrier at bulk rates. Acme Fast Freight, Inc. v. United States, 30 F. Supp. 968, 969-70 (S.D.N.Y.), aff'd per curiam, 309 U.S. 638 (1940). Their services are distinguishable, however. The freight forwarder, as compared with the pure reseller, typically collects, consolidates, re-sorts, and delivers the goods, thus exercising some degree of control over the shipment. Id. at 970 .

79 Id. at 971-73; Freight Forwarding Investigation, 229 I.C.C. 201, 303 (1938); see Motor Carrier Act of 1935, ch. 498, § 203(a)(14), 49 Stat. 544 (1935) (repealed 1978). The current version appears at 49 U.S.C. $\S \S 10102(8), 10561-10562$ (Supp. II 1978).

so Act of May 16, 1942, ch. 318, 56 Stat. 284 (repealed 1978).

${ }^{31}$ Act of Dec. 20, 1950, ch. 1140, 64 Stat. 1113 (repealed 1978).

${ }^{82}$ Communications Act of 1934 § 3(h), 47 U.S.C. § 153(h) (1976).

${ }^{83}$ Id. § 3(a), (b), 47 U.S.C. § 153(a), (b) (1976).

84 Ahearn, Freight Forwarders and Common Carriage, 15 Fordham L. Rev. 248, 253-60 (1946).

${ }^{8 s}$ See text and note at note 22 supra. 
over, the ICC apparently had not clarified its position on freight forwarders until after passage of the Communications Act; ${ }^{86}$ hence, Congress could not have intended a reference to the ICC's subsequent anti-common law position. ${ }^{87}$

Finally, three policy considerations counsel treating resellers as common carriers. First, lack of control over the transmission facilities does not render a firm offering communication services any less capable of engaging in unreasonable pricing, price discrimination, or arbitrary withholding of such services. Therefore, regulation of resellers is just as appropriate as regulation of underlying carriers. ${ }^{88}$ Second, nonregulation of resellers could also shield the underlying carrier from regulation. If a carrier were to lease all of its capacity to one party, an unregulated reseller, it would properly escape FCC jurisdiction because it would be a private carrier, not

so See Freight Forwardeng Investigation, 229 I.C.C. 201 (1938). That decision contains no discussion of any earlier ICC resolution of the issue.

${ }^{87}$ An additional reason has been offered for not following the ICC's treatment of freight forwarders: contrary to the Interstate Commerce Act, the Communications Act specifically mentions the "forwarding ... of communications" as a common carrier activity, Communications Act of 1934 § 3(a), (b), 47 U.S.C. § 153(a), (b) (1976). See AT\&T v. FCC, 572 F.2d 17, 25 (2d Cir.), cert. denied, 439 U.S. 875 (1978). But this distinction does not, standing alone, necessarily render the ICC analogy inapplicable. First, the Senate Report on the Communications Act explains that deviations from the language of the Interstate Commerce Act "are made for clarification [of the terms"] application to communications, rather than as a manifestation of Congressional intent to obtain a different objective." S. REP. No. 781, 73d Cong., 2d Sess. 2 (1934). Second, the term "forwarding" has a specialized meaning in the transportation context, denoting the consolidation into bulk lots and re-sorting and delivery of goods, whereas its use in the communications context clearly is intended to be in the normal sense of the word. See Communications Act of $1934 \S 3(\mathrm{a})$, (b), 47 U.S.C. $\S$ 153(a), (b) (1976) (transmission includes "the receipt, forwarding, and delivery of communications").

ss One might argue that, to the extent resellers operate in a competitive market, they are not capable of, nor do they have the incentive to engage in, unreasonable pricing, price discrimination, and refusal of services because they would not enjoy monopoly power. See Competitive Carrier Rulemaking, 77 F.C.C.2d 308, 316-17 (1979). This argument is essentially the one addressed at text and notes at notes 163-176 infra, namely, that Congress did not intend to regulate competitive carriers of any kind. There, it is concluded that Congress did intend to regulate competitive as well as monopolistic carriers. Thus, even if such a policy is thought unwise from an economic standpoint, it is proper to use it as a guide to construction of the Act because it is the policy that Congress intended. Moreover, even if Congress did not intend to regulate competitive carriers, the policy analysis here is valid with regard to resellers that do enjoy monopoly power-and some degree of monopoly power is in fact likely because of the degree of service differentiation that results from the highly individualized nature of the technical services offered by resellers, see note 89 infra. Thus the FCC's reasoning that all resellers must be constrained by the competition from the underlying carrier's tariffed rates, Competitive Carrier Rulemaking, No. 79-252, I 129 (F.C.C. Jan. 16, 1981), applies only where the reseller performs a simple brokerage function, and its service thus is the same as that of the underlying carrier. 
holding out to the public. Congress could not reasonably have intended to allow all parties to exempt themselves from regulation by purposefully divorcing the transmission function from the public marketing function. Third, those resellers that enhance the underlying service can be viewed as exercising sufficient control over the transmission to warrant treatment as carriers and thus should be regulated. ${ }^{8 \theta}$

\section{Engaged in Communication}

Generally speaking, to come within the FCC's common carrier jurisdiction, a firm must offer a communication service; $;^{90}$ that is, it must transmit messages of some sort.1 This observation, vacuous as it may sound, has caused the Commission some difficulty in the past. The Western Union Company at one time offered such services as flowers and gifts by wire, candygrams, cigargrams, and even dollygrams, and still offers a money order service. In such services, a communication function-the sending of the message by telegraph to the delivery office-is combined with a merchandising function-the sale and delivery of the flowers, dolls, and so forth. The Commission correctly ruled that the former was common carriage but the latter was not. ${ }^{22}$ Although there is an information content in the mere delivery of the flowers and dolls, that message is not communicated by "wire or radio" and thus is not the type of communication governed by the Act. ${ }^{93}$

89 " $[\mathrm{M}]$ any resellers ... utilize switches ... to perform alternate routing, queuing, timing, billing, authorization code and other functions . . . [and] are thus directly involved with the transmission pipeline." Reply Comments of AT\&T at 49, Competitive Carrier Rulemaking, No. 79-252 (F.C.C. April 4, 1980) (on file with The University of Chicago Law Review).

${ }^{\text {go }}$ See Public Notice No. 1694, at 2-3, (F.C.C. Nov. 5, 1964) [hereinafter cited as Public Notice] (on file with The University of Chicago Law Review).

${ }^{91}$ See Communications Act of 1934 § 3(a), (b), 47 U.S.C. § 153(a), (b) (1976) ("Communication . . . means transmission of writing, signs, signals, pictures, and sounds").

${ }^{22}$ See Public Notice, supra note 90; Activities of Regulatory and Enforcement Agencies Relating to Small Business: Hearings Before Subcomm. No. 6 of the House Select Comm. on Small Business, 89th Cong., 2d Sess. 18-19 (1966) (testimony of E. William Henry).

Western Union's money order service was not detariffed until 1979. See Western Union Tel. Co., Statement Describing Services Not Covered by Tariffs (Mar. 8, 1979) (on file with The University of Chicago Law Review).

The delivery of flowers and other products would not properly be treated as an incidental service within the meaning of the statute, because such service does not involve the "receipt, forwarding, and delivery of communications," Communications Act of 1934 §(a), (b), 47 U.S.C. $\$ 153(a)$, (b) (1976) (emphasis added).

${ }^{83}$ The reason the sending of the telegraph message is regulated despite being incidental 
When messages are transmitted by wire or radio, however, the information content can be quite rudimentary and still come within the FCC's jurisdiction. For example, a paging service may be conducted on a common carrier basis ${ }^{94}$ even though the intelligence transmitted is only a "beep" signifying that the recipient should call a prearranged number. Liketwise, cable television systems constructed with two-way capacity enabling the home viewer to respond to questions ${ }^{95}$ involve common carriage. ${ }^{96}$ Finally, the requirement of even a rudimentary information content disappears when transmission occurs by radio rather than by wire. Any person engaged in "transmission of energy by radio" can be a common carrier if the other elements of the definition are met. ${ }^{.7}$ For example, a company that held itself out for hire to beam solar energy to earth by microwave would be defined as a common carrier even though no communication is involved.

\section{For Hire}

This element of the definition is well grounded in common law. A common carrier must be an entrepreneur; ${ }^{88}$ gratuitous services are not regulated. ${ }^{99}$ Compensation may be implicit, however. For example, if a third party, the parent corporation of the carrier, charges for the services of the carrier, compensation to the carrier in the form of stock dividends will render the service "for hire."100

Because a firm does not have to operate at a profit to be making an offering "for hire," the compensation element has arisen in FCC decisions to date only in the context of holding out. As discussed above, ${ }^{101}$ the Commission has taken the position in certain cases that if a carrier operates on a nonprofit basis, this is a sufficient indication of an intent not to hold one's services out to all potential users, so that the entity will be considered a private car-

\footnotetext{
to the sale of the flowers or candy is discussed in text at notes 139-141 infra.

- See Xerox Corp., 74 F.C.C.2d 471, 482 (1979).

ss See Chi. Tribune, May 27, 1980, § 5, at 1, col. 1 .

96 National Ass'n of Regulatory Util. Comm'rs v. FCC (NARUC II), 533 F.2d 601, 610 nn.44-46 (D.C. Cir. 1976) (opinion of Wilkey, J.) [hereinafter cited as NARUC II].

${ }^{27}$ Communications Act of 1934 § 3(d), (h), 47 U.S.C. § 153(d), (h) (1976) (emphasis added).

os 13 AM. JuR. 2D Carriers $\$ 3$ (1964).

"9 Communications Act of 1934 § 3(h), 47 U.S.C. § 153(h) (1976).

${ }^{100}$ Cf. Lone Star Steel Co. v. McGee, 380 F.2d 640, 647 (5th Cir.), cert. denied, 389 U.S.

997 (1967) (a transportation case).

${ }^{102}$ See text and note at note 35 supra.
} 
rier. ${ }^{102}$ Sharing of communication facilities on a nonprofit basis is therefore generally not common carriage, ${ }^{103}$ not because it is not done for hire, but because it is not a public offering. If an indiscriminate offering to the public is in fact being made, a firm will be considered a common carrier despite its nonprofit status. ${ }^{104}$ This sensible distinction renders the holding out element more predictable.

\section{E. Not Broadcasting}

"A person engaged in radio broadcasting shall not ... be deemed a common carrier." 105 This relatively uncontroversial element of the definition is grounded in two policy concerns. ${ }^{108}$ The first is that Congress feared that excessive regulation would inhibit development and utilization of the radio spectrum and would cripple a still-young industry. ${ }^{107}$ The second is the concern that excessive regulation, particularly the duty to serve indiscriminately, might supress the journalistic freedom that broadcasters were intended to enjoy. ${ }^{108}$ The latter rationale has been stressed in recent years. For example, in its 1979 decision FCC $v$. Midwest Video Corp., ${ }^{109}$ the Supreme Court held that the FCC could not impose

${ }^{102}$ See AT\&T v. FCC, 572 F.2d 17, 26 (2d Cir.), cert. denied, 439 U.S. 875 (1978).

${ }^{103}$ Resale \& Shared Use of Common Carrier Servs. \& Facilities, 60 F.C.C.2d 261, 316 (1976). Nonprofit operations were also relied upon to find non-common carriage in Special Emergency Radio Serv., 24 F.C.C.2d 310, 314 (1970).

${ }_{104}$ See AT\&T v. FCC, 572 F.2d 17, 26-27 (2d Cir.), cert. denied, 439 U.S. 875 (1978).

105 Communications Act of 1934 § 3(h), 47 U.S.C. § 153(h) (1976). Television broadcasting is encompassed in "radio broadcasting." Id. $\S 3(\mathrm{~b}),(\mathrm{o}), 47$ U.S.C. $\S 153(\mathrm{~b})$, (o) (1976).

Broadcasting is the dissemination of radio communications intended to be received by the public. Id. § 3(o), 47 U.S.C. § 153(o) (1976). Thus, radio transmission intended only for a limited or private audience, such as paging, may constitute common carriage. Although the Commission has not squarely addressed the issue, its position apparently is that companies that simply transmit television programs to the public as a service for acknowledged broadcasters are themselves not broadcasters. See Matrock Corp., 73 F.C.C.2d 802, 803 \& n.5 (1979) (dictum) (distribution of programs to pay television subscribers is common carriage). It is not clear whether this position is based on the theory that such carriers do not "intend" reception by the public, or on the theory that such carriers do not "disseminate" because they transmit only on behalf of the broadcaster, rather than on their own behalf. The latter rationale is the more plausible, although both would convert an ordinary word into a term of art.

${ }^{108}$ A third rationale, that Congress chose not to impose Title II regulation on broadcasters because the industry is not subject to natural monopoly conditions, is mentioned in FCC v. Sanders Bros. Radio Station, 309 U.S. 470, 474-76 (1940).

${ }^{107}$ See Note, 1979 WIs. L. REv. 962, 981-82.

108 See CBS v. Democratic Nat'l Comm., 412 U.S. 94, 105-110 (1973) (broadcasters are not under a duty to serve all advertisers).

109440 U.S. 689 (1979). 
on cable television operators the common carrier obligation of offering channel capacity for others' transmissions because that industry is sufficiently similar to broadcasting to invoke the policy contained in the Act's exclusion of broadcasters from common carriage. ${ }^{110}$

F. The Press Association Principle: Primarily a Noncommunication Service

1. The Principle. The legislative history of the Act makes clear that a press association such as UPI and AP is not to be considered a common carrier. ${ }^{111}$ The congressional reports do not indicate why this is so, however, ${ }^{112}$ and one might readily conclude that the distribution of communications in the form of press releases for hire would be common carriage. An examination of the historical application of "common carrier" resolves this issue. At common law, a person who carries goods to which he has title is not a common carrier. ${ }^{113}$ Rather, he is viewed as a merchandiser of the goods carried. Although a transportation service is implicitly included in the purchase price of goods to be delivered, it is viewed as a mere incident to the primary activity, the sale of the goods. ${ }^{114}$ This precedent applies to press associations by analogy. By virtue of the labor invested, press associations have been viewed as having certain property rights in the stories they research and write. ${ }^{115}$ Thus, although part of UPI's and AP's subscription rate applies to the service of transmitting the information to subscribers, such charges are properly not tariffed because they are merely incidental to the sale of the news. On the other hand, the telephone and telegraph companies that transmit the news stories for UPI and AP are

$110 \mathrm{Id}$. at 702-08.

111 H.R. Cons. Rep. No. 1918, 73d Cong., 2d Sess. 46 (1934); H.R. ReP. No. 1850, 73d Cong., 2d Sess. 4 (1934).

112 The House reports, see note 111 supra, might be read as reasoning that press associations are not common carriers because they tend to individualize their services. When they are read in light of the circularity inherent in the definition, however, it is clear that Congress meant that press associations are allowed to individualize their offerings because they are not common carriers.

${ }^{113}$ See The Pipe Line Cases, 234 U.S. 548, 559-61 (1914); cf. New Hampshire Pub. Utils. Comm'n v. Naughton, 394 A.2d 311, 312-13 (N.H. 1978) (trash collectors are not common carriers because title in the trash is impliedly transferred to the collector).

114 See Lloyd McKee Motor, Inc. v. New Mexico State Corp. Comm'n, 93 N.M. 539, 542, 602 P.2d 1026, 1029 (1979).

${ }^{118}$ See International News Serv. v. Associated Press, 248 U.S. 215, 234 (1918). 
treated as common carriers ${ }^{118}$ because they have no interest in the intelligence transmitted.

2. Cable Television. This analysis explains another major FCC common carrier precedent. In its Frontier Broadcasting Co. decision, ${ }^{112}$ the Commission ruled that cable television operators, which resemble common carriers in that they transmit television signals for hire, are not common carriers. ${ }^{118}$ Its rationale was that whereas common carriers transmit intelligence of a customer's design and choosing, cable operators receive and distribute signals determined by the operator rather than the subscriber. ${ }^{10}$ This decision has been interpreted as establishing a principle unique to the communications field. ${ }^{120}$ Such an interpretation is incorrect, because a regulatory agency has no authority to tamper with its statutory directive by adding or subtracting provisions. ${ }^{121}$ Rather, the FCC's decision reflects a proper application of the common law press association principle referred to in the Act's legislative history. ${ }^{122}$ Cable operators can be viewed as having a property interest in the programs they transmit to their subscribers because the operators select the programs and pay royalties for their transmission, ${ }^{123}$ and some cable operators even produce and distribute their own programs. ${ }^{124}$ To the extent that cable operators do not engage in such activities, however, their services might properly be

${ }^{116}$ See Subscription Television Serv., 3 F.C.C.2d 1, 10 (1966).

11724 F.C.C. 251 (1958).

118 Id. at 253-55. Note that the statutory broadcaster exclusion does not apply to cable operators because the FCC has determined that they are not engaged in broadcasting, CATV \& TV Repeater Servs., 26 F.C.C. 403, 427-28 (1959).

112 24 F.C.C. at 253-55.

120 See NARUC II, 533 F.2d 601, 609 (D.C. Cir. 1976).

121 Cf. NARUC I, 525 F.2d 630, 644 (D.C. Cir.) ("The common law definition of common carrier is sufficiently definite as not to admit of agency discretion in the classification of operating communications entities"), cert. denied, 425 U.S. 992 (1976).

123 Cf. Letter to J.E. Belknap \& Assocs., 43 F.C.C. 1562, 1562-63 (1953) (suggesting that a microwave distributor of television signals is either a "common carrier of communications" or a "vendor of program materials" according to whether the distributor has any "property rights" in the signal).

123 The copyright royalty payment provision for cable operators is found at 17 U.S.C. § 111(d)(2) (Supp. III 1979). But see Western Union Tel. Co., 14 F.C.C. 1026, 1028-29 (1950) (holding that a service whereby Western Union furnishes news reports of sports events is common carriage despite payment by Western Union to the baseball clubs for the right to disseminate the information; the Commission reasoned that, according to the terms of the contract with the clubs, Western Union acquired no property rights in the news).

124 For the same reasons, broadcasters are not common carriers in delivering their programs. This rationale would not apply to the service of selling air time to advertisers, however, see text and note at note 125 infra, and thus the statutory exemption discussed in text at notes 105-109 supra is needed to preclude common carrier regulation entirely. 
considered common carriage. For example, if a cable operator were merely a conduit for the distribution of programs by a third party, it would be engaged in common carriage. ${ }^{125}$

3. Basic Versus Enhanced Services. A third application of this principle can be seen in the Commission's Final Decision in its Second Computer Inquiry rulemaking. ${ }^{126}$ In that case the FCC addressed the problem of how to regulate the myriad of computerrelated services that have been introduced into the telecommunications industry over the past two decades. ${ }^{127}$ It decided to continue regulating "basic" communication services but to treat "enhanced" services as non-common carriage. ${ }^{128}$ Basic services are those that affect the subscriber's message only to the extent necessary to facilitate transmission of the message. ${ }^{120}$ Enhanced services are those that "employ computer processing applications that act on the format, content, code, protocol, or similar aspects of the subscriber's transmitted information; provide the subscriber additional, different, or restructured information; or involve subscriber interaction with stored information."1so

This decision to treat enhanced communication services as non-common carriage arguably falls under the press association

${ }^{135}$ FCC v. Midwest Video Corp., 440 U.S. 689, 700-02 (1979).

The intriguing issue of whether a cable system falls under the Frontier Broadcasting precedent if it is organized such that the cable operator transmits only those programs or stations that a majority of his subscribers request (as determined by a vote), was presented in CATV \& TV Repeater Servs., 26 F.C.C. 403 (1959). The Commission held such an operator not to be a common carrier because the minority of subscribers still have no choice. Id. at 428. This reasoning is not persuasive. Because the cable operator exerts no control over the content of this transmission, and has to pay no royalites, see 17 U.S.C. $\$ 111$ (a)(3) (Supp. III 1979), he has no property interest in the transmission. Furthermore, the primary service becomes one of transmitting to the subscriber, for a fee, those signals he wishes to see. This is a simple communication service rather than a programming service. In such a situation, the cable operator's role is the same as that of the telephone or telegraph company in its relationship to UPI, except that the subscriber, rather than the sender of the communication, pays the bill.

12877 F.C.C.2d 384 (1980).

${ }^{127}$ The Second Computer Inquiry decision represents the latest attempt by the FCC to solve a problem with which it has struggled for 10 years. Prior attempts include the Tentative and Final Decisions in its First Computer Inquiry, Computer Use of Communications \& Facilities, 28 F.C.C.2d 291 (1970) (Tentative Decision); 28 F.C.C.2d 267 (1971) (Final Decision), aff'd in part sub nom. GTE Serv. Corp. v. FCC, 474 F.2d 724 (2d Cir. 1973), and the Tentative Decision in the Second Computer Inquiry, 72 F.C.C.2d 358 (1978). For a description of these services, see J. MARTIN, supra note 76.

${ }^{128} 77$ F.C.C.2d at 387 . The attempt to distinguish between data processing and communications was abandoned. Id. at 390,428 .

129 Id. at $419-21$.

13045 Fed. Reg. $31,319,31,364-65$ (1980) (to be codified in 47 C.F.R. $\S 64.702(a)$ ). 
principle. If the carrier alters the content of the information transmitted, or provides additional or different information, it either is exercising control over the communication analogous to that exercised by cable operators, or it has a property interest in the content analogous to that of the wire services. ${ }^{131}$ In such cases, it is probable that the consumer is seeking the enhancement service and that the transmission is a mere incident to that service. ${ }^{132}$ Likewise, when the enhancement does not alter content but provides services not involving communication, such as allowing a subscriber to store and retrieve information, the primary service might well be the noncommunication one. The decision in the Second Computer Inquiry can be faulted, however, for making this presumption of primacy too sweeping. The Commission has abandoned its former position whereby mixed communication and computer services were examined to determine which predominated. ${ }^{133}$ Although this may have proven administratively burdensome, ${ }^{134}$ such a burden is perhaps necessary due to the large variety of enhanced services that exist. Moreover, the present approach apparently would allow the provider of a service that is primarily communication to avoid regulation by adding a minor enhanced service that is irrelevant to the consumer. Additionally, even if a communication service is truly incidental to a computer service, and thus is not regulated according to the precedents analyzed so far, there is a modification of this principle, discussed below, ${ }^{135}$ holding that if the communication and computer services are offered by a firm otherwise engaged in common carriage, the communication service will be regulated despite its incidental character.

4. Recapitulation. Three examples of the common law principle that a carrier of his own goods is not a common carrier have been provided: press associations, cable television, and computer enhancement services. They demonstrate a progressive weakening of the notion that the carrier has a property right in the thing carried; this progression culminates in the example of a storage and retrieval service where it becomes implausible to assert such an interest. This problem does not arise from application of the transportation analogy; rather, it shows that the press association prin-

131 See 77 F.C.C.2d at 430.

132 See id. at 435.

1ss See 47 C.F.R. $\S 64.702(a)(5)$ (1979) (current version at 45 Fed. Reg. 31,319, 31,364 (1980)).

134 See 77 F.C.C.2d at 430.

195 See text and notes at notes 139-141 infra. 
ciple is based on the broader reasoning that a communication service incidental to a noncommunication service is not common carriage. A property interest in the information transmitted therefore is not necessary to invoke the principle. ${ }^{136}$ What is essential is that the actions establishing dominion or control over the content of the information constitute the service in which the customer is primarily interested. Because the primacy of the noncommunication service is the heart of the principle, the principle is properly applied to cases such as information and retrieval services that involve no carrier control over the message content. ${ }^{137}$

Problems of application can arise in determining the incidental nature of the communication service. First, the nature of the primary service must be kept clearly in view in order to determine whether it is indeed a noncommunication service, for an advocate might attempt to avoid regulation by calling a common carrier activity an enhanced service. ${ }^{138}$ The second problem arises when a firm that is primarily a common carrier undertakes noncommunication services involving incidental communication services. It is clear that common carriers may engage in non-common carrier activities without those services being subject to regulation. ${ }^{138}$ At first glance, the press association principle suggests that the incidental communication services should also remain free from regulation. The FCC, however, has taken the position that the telegraph charges incidental to Western Union's flowers-by-wire, candygram, and gifts-by-wire services are to be tariffed. ${ }^{140}$ This modification of the press association principle is consistent with its

136 Thus the decision in Western Union Tel. Co., 14 F.C.C. 1026 (1950), is incorrect to the extent that it suggests that a firm can retain common carrier status by contracting away the property rights in the information transmitted before transmission, see note 123 supra. The decision is correct, however, on the grounds discussed in text at notes 139-141 infra, namely, that the offeror was already regulated as a common carrier. See note 140 infra.

${ }_{137}$ Similarly, a news wire service is not common carriage because the primary service is the collection and writing of the news stories; cable service is not common carriage because it is primarily an entertainment service-the selection and packaging of programs.

13 For example, a company might be the lessor of radio devices, operated on frequencies licensed to that company, to be used in a geological survey. See Industrial Radiolocation Serv., 5 F.C.C.2d 197 (1966). It could be argued that the provision of such a service is non-common carriage because providing the radio equipment and licensing the frequency is incidental to an engineering service. See id. at 201 (position not adopted by FCC). The engineering service itself, however, involves the transmission of energy and thus is a common carrier activity. See text and note at note 98 supra.

139 See FCC v. Midwest Video Corp., 440 U.S. 689, 701 n.9 (1979).

140 See text and note at note 92 supra. The FCC has also regulated Western Union's sports news service. See notes 123, 136 supra. In neither case, however, did the FCC employ the reasoning advanced here. 
rationale because it would be more troublesome to isolate and detariff such charges than it would be to continue regulation. Moreover, this exception to the general rule prevents established carriers from attempting to avoid regulation by adding noncommunication services across the board and claiming that they are the primary ones. On the other hand, a flowers-by-wire service offered by the Florists Transworld Delivery Association, a non-common carrier, is entirely unregulated even though the service is essentially identical to that offered by Western Union. ${ }^{141}$

5. Misapplication. This comment has discussed only the consistent applications of the press association principle thus far. In fact, there has been general misunderstanding of this principle, primarily reflected in the misconstruction of the cable television precedent. As discussed above, the proper basis of that decision is that the cable operator, by choosing and packaging the signals, is offering primarily an entertainment service. ${ }^{142}$ The FCC, however, has viewed the decision as establishing the principle that lack of substantial customer control over the intelligence transmitted renders a service non-common carriage. ${ }^{143}$

Such a principle is inappropriate for several reasons. First, as previously mentioned, the principle would be sui generis to communications if it were adopted, and thus beyond the common law guidelines that Congress has mandated for the construction of the term "common carrier." Second, it is inconsistent with other precedents. For example, in a letter to the Florists' Telegraph Delivery Service, the Commission expressed the view that the transmission of messages to accompany the gift of flowers "might well

141 See text and note at note 145 infra. The charge for flowers is not tariffed in either case, however. See text and notes at notes 90-97 supra.

142 See text and notes at notes 117-119 supra.

${ }^{443}$ See Competitive Carrier Rulemaking, 77 F.C.C.2d 308, 367 (1979). For example, the Commission held in Industrial Radiolocation Serv., 5 F.C.C.2d 197 (1966), that a company that leased geological exploration radar equipment to customers, operating on frequencies licensed to that company, was not a common carrier because "the radio facilities . . . cannot . . . be used to transmit any intelligence of the design and choice of the customer." Id. at 202. The Commission did go on to conclude that "the specific intelligence transmitted is and must be the sole responsibility and prerogative of the licensee." Id. There seems to be no basis for this assertion, however, other than the licensee's statutory duty to limit the use of the allocated spectrum to permissible purposes. Yet such a duty exists in all radio licensee cases, and if it were sufficient to invoke the Frontier Broadcasting precedent, there would be no such thing as a radio common carrier. Rather, it is the geological formations at which the radio equipment is aimed that determine the content of the transmission, not the licensee or the subscriber.

14 See text and notes at notes 120-121 supra. 
be" common carriage, irrespective of "whether such messages were chosen from fixed texts or prepared by the sender."140 Another contrary example is paging, which is viewed as common carriage even though the subscriber's choice is limited to only one message-a beep. ${ }^{148}$ Finally, misconstruction of the cable precedent can create difficulties in reaching the correct result in certain cases. For instance, as the capacity of cable systems increases to dozens of channels, ${ }^{147}$ it becomes unconvincing to argue, as the FCC apparently would, that a subscriber has no significant control over the content of the communications he pays to receive. Yet if the cable operator's control, rather than the viewer's lack of control, is the focus of the inquiry, such a case is easy: the operation would continue to be non-common carriage because the cable operator, in performing the same services as before, continues to offer primarily an entertainment service, only now the service involves a larger number of programs. ${ }^{148}$

\section{A New Element: Market Power}

The FCC has tentatively decided that "communication suppliers without market power need not be treated as common carriers",; ${ }^{149}$ this would make power over price a jurisdictional prerequisite. The Commission used the following argument in favor of this additional element in the definition of common carrier. In the English common law development of common carrier status, common carriage was seen as one instance of the large class of professions known as "public callings." Possession of a monopoly was a necessary characteristic of being engaged in a public calling. American courts concurred because a monopolistic position was considered

143 Public Notice No. 1630 (F.C.C. Dec. 6, 1951) (on file with The University of Chicago Law Review). Similarly, a Western Union service, the Melodygram, whereby the customer could order any one of 10 prerecorded discs containing a song, was tariffed at one time. See Melodygram Serv., F.C.C. Tariff No. 250, at 3 (Sept. 1966) (on file with The University of Chicago Law Review).

140 See text and note at note 94 supra. If the principle of customer control were applied to "collect" telegrams and telephone calls, which have consistently been considered common carrier services, these activities would necessarily be beyond the FCC's jurisdiction because the party paying for the services does not determine the content of the incoming message.

147 See J. MARTIN, supra note 76, at 135-41.

148 A department store that delivers its own goods is no more a common carrier than is a grain merchant who delivers his, despite the greater choice the consumer has in the nature of the goods transported.

119 Competitive Carrier Rulemaking, No. 79-252, I 8 (F.C.C. Jan. 16, 1981); see id. I 56 $\&$ n.43. 
constitutionally necessary to subject businesses to pervasive entry, exit, and rate regulation of the type imposed by the Communications Act. Finally, Congress's intent was to regulate only carriers with market pqwer because in 1934 when the Act was passed common carriers were monopolistic, and because the purpose underlying the scheme of regulation in Title II was to prevent monopolistic abuses. ${ }^{150}$ This argument is both analytically and factually defective, however.

First, the reading of English common law is erroneous. Edward Adler, in a comprehensive and discerning analysis, explains that "[n]owhere is monopoly suggested as the distinguishing characteristic" between private and common carriers, nor did "common" mean monopolistic;"151 rather, "the word 'common' describes the nature of the undertaking" and could be applied to any business whatsoever if conducted in a public, as opposed to a private, manner. ${ }^{162}$ As between public and private callings generally, "[m]onopoly . . . cannot be accepted [as the distinguishing factor] . . . either at present or in the distant past," because innkeepers, smiths, farriers, and tailors, considered to be people engaged in public callings, were no less numerous than butchers, carpenters, and weavers, who were not so considered. ${ }^{163}$

In American law, the monopolistic character of rate-regulated industries was viewed for only a very short time as the essential feature sustaining the constitutionality of such regulation. ${ }^{184}$ The Supreme Court used language to this effect in $1876^{155}$ and again in 1892. ${ }^{156}$ In 1894, however, the Court affirmed North Dakota's regu-

${ }^{130}$ Id. III 11-53, App. B.

${ }^{151}$ Adler, Business Jurisprudence, 28 HaRv. L. REv. 135, 156 (1914).

${ }^{162}$ Id. at 152. See generally id. at 149-56.

18s Id. at 149. An argument contrary to that made by Adler is presented by Wyman, The Law of the Public Callings as a Solution to the Trust Problem (pts. 1-2), 17 Harv. L. REv. 156, 217 (1903-04): "Upon the whole the circumstances surrounding these [surveyed] cases suggest this as the characterizing thing; that in the private calling the situation is that of virtual competition, while in the public calling the situation is that of virtual monopoly." Id. at 161 .

Adler has the better argument. As Wyman himself observes, no explicit reliance on monopolistic status is made in the cases; he can only say that "circumstances . . . suggest" this as the critical factor. Even then, the circumstances were not consistently monopolistic.

${ }^{154}$ Even to the extent that it was so considered, this does not support the proposition that monopoly was considered a necessary element of the definition of common carrier. See text and notes at notes $161-162$ infra.

${ }^{155}$ Munn v. Illinois, 94 U.S. 113 (1876). In that case, the Court upheld an Illinois law regulating grain elevators, mentioning during a general description of the business that it "may be a 'virtual' monopoly." Id. at 131.

${ }^{158}$ In Budd v. New York, 143 U.S. 517 (1892), the Court viewed monopolistic status as 
lation of grain elevators where conditions were highly competitive, ${ }^{157}$ and twice thereafter, in $1914^{158}$ and $1934,{ }^{168}$ the Court expressly rejected monopoly conditions as a controlling rationale. ${ }^{\mathbf{1 6 0}}$

The analytical defect in reliance on early English and American law is that it confuses the purpose of regulation with the description of the class of businesses regulated. In other words, even if common carriers were not regulated unless they were also monopolies, this does not mean that a company had to be monopolistic to be described as a common carrier. "Common carrier" is a discrete concept, separate from either "monopoly" or "public calling." Thus even if monopoly is a necessary element of a public calling, this shows only that common carriers were first regulated because they were typically monopolies. ${ }^{162}$ Congress, however, has imposed regulation on all common carriers regardless of their monopolistic status.

Second, although the strong market positions of the telephone and telegraph companies constituted the principal reason for the enactment of Title II's scheme of regulation, ${ }^{163}$ Congress was aware that competitive conditions existed in certain parts of the industry circumscribed by its use of the term "common carrier." The existing telegraph systems were viewed as "fully" and "highly competitive" and "substantially all points reached by . . . all the major competitors in the wireless field" experienced competitive conditions. ${ }^{164}$ An additional indication that Congress did not consider the term common carrier necessarily limited to firms with market

being the decisive factor determining the quasi-public character of the business. Id. at 545 .

137 Brass v. North Dakota ex rel. Stoeser, 153 U.S. 391, 402-03 (1894).

168 German Alliance Ins. Co. v. Kansas, 233 U.S. 389, 410 (1914).

189 Nebbia v. New York, 291 U.S. 502, 534-35 (1934).

100 See generally McAllister, Lord Hale and Business Affected with a Public Interest, 43 HARv. L. REv. 759, 767-72 (1930).

161 See Competitive Carrier Rulemaking, No. 79-252, App. B If 43 (F.C.C. Jan. 16, 1981); NTIA Comments, supra note 42, at 14 ("The law on public callings was . . applicable to common carriers because . . . monopoly conditions existed in transportation").

162 Nowhere does the FCC cite an instance where firms within an industry were classified as common carriers vel non on the basis of monopoly power. Rather, particular occupations were classified as public callings in part because monopoly conditions predominated, one such occupation being that of common carriage. See Competitive Carrier Rulemaking, No. 79-252, App. B กा 5-17, 37-46 (F.C.C. Jan. 16, 1981).

18s See S. Rep. No. 781, 73d Cong., 2d Sess. 2 (1934). See also Competitive Carrier Rulemaking, No. 79-252, I 6 (F.C.C. Jan. 16, 1981).

${ }_{164}$ H.R. ReP. No. 1273, 73d Cong., 2d Sess. 90, 961, 998 (1934). Other comments on competitive conditions appear elsewhere in the legislative history. See H.R. REP. No. 1850, 73d Cong., 2d Sess. 3 (1934) (directing the FCC to investigate the effect of exclusive contracts for telegraph offices on "other competing carriers"). 
power is that, one year after the enactment of the Communications Act, it passed the Motor Carrier Act of $1935,{ }^{165}$ using "common carrier" to regulate "relatively competitive carrying industries."186

Finally, policy considerations disfavor complete deregulation of competitive carriers. The scheme of entry, exit, and rate regulation found in Title II is designed to do more than prevent monopolistic abuse. ${ }^{167} \mathrm{~A}$ firm might discriminate in rates or refuse services for noneconomic reasons, practices that sections 201 and 202 specifically prohibit. ${ }^{168}$ Without the section $214(\mathrm{~d})$ power to compel extension of service, ${ }^{169}$ less profitable areas might be deprived of needed communications capacity. The control of firm entry ${ }^{170}$ is needed where it is desirable to preserve monopolistic conditions in certain markets; for example, if start-up costs are high, ${ }^{171}$ a period of guaranteed reduced competition might be necessary to induce development of a new technology. ${ }^{172}$ Moreover, competitive conditions may bring with them destructive side effects. Problems of incompatible equipment or resistance to carrier-to-carrier interconnection may arise, ${ }^{173}$ and competition in the form of quality and

${ }_{165}$ Ch. 498, 49 Stat. 543 (repealed 1978).

${ }^{368}$ NARUC I, 525 F.2d 630, 641 (D.C. Cir.), cert. denied, 425 U.S. 992 (1976).

${ }^{167}$ See 1 A. KAHN, supra note 47, at 11 (economic justifications for the institution of regulated monopoly include the control of important industries, the protection of the consuming public, and the recognition of economies of scale and ineffective competition).

It should be noted that although Title $I I$ is designed to correct the harmful practices that can occur in a competitive market, the FCC might be able to correct some or all of these practices without Title II jurisdiction through its "ancillary or Title I" jurisdiction. See text and notes at notes 7, 60 supra. Cf. 47 C.F.R. $\$ \S 76.59$ (a), 76.61(a) (1979) (imposing a limited common carrier duty on cable television operators to carry the television signals of stations that are in the same region as the cable company).

${ }^{188}$ Communications Act of $1934 \S \S 201-202,47$ U.S.C. $\S \S 201-202$ (1976).

${ }^{180}$ Id. § 214(d).

170 See id. \& 214(a).

${ }^{171}$ Such is the case, for example, with satellite systems because of the high initial launching and equipment costs. See Competitive Carrier Rulemaking, 77 F.C.C.2d 308, 320 (1979).

${ }^{172}$ Cf. 2 A. KAHN, supra note 47, at 173:

The major prerequisites [of destructive competition] are fixed or sunk costs that bulk large as a percentage of total costs; and long-sustained and recurrent periods of excess capacity. These two circumstances describe a condition in which . . . the possibility arises that the industry as a whole, or at least the majority of its firms, may find themselves operating at a loss for extended periods of time.

Similarly, a sustained monopoly may be beneficial where an industry exhibits natural monopoly characteristics. See text and note at note 47 supra.

173 See Ferris, Common Carrier Regulation for the Future, 17 HARv. J. LEgrs. 241, 24647 (1980) (competition has created new regulatory problems such as "incompatible terminal equipment which would harm the overall telephone network," and requires regulation to achieve "carrier-to-carrier interconnection on equitable terms") (Mr. Ferris is Chairman of 
capacity cutting or quality upgrading may lead to unreliable service or unnecessary extras. ${ }^{174}$ Because of such problems, it is unwise to pose a "once-and-for-all choice between competition and regulation, since either system is subject to imperfections of varying intensity and mischievousness."175 The preferable course is the one that the Commission has recently set: de minimis regulation of competitive carriers, ${ }^{176}$ preserving common carrier jurisdiction to correct destructive practices whenever necessary. Even if the existing scheme of regulation is inappropriate in today's communications market, because of its much more competitive climate, wholesale revision of the Act is more appropriately undertaken by Congress than by the Commission. ${ }^{177}$

\section{CoNCLUSION}

In its details, the FCC's application of the term "common carrier" reflects a moderately successful jurisprudence. The basic common law elements of the term have been preserved-namely, a holding out of services for hire to the public at large, a certain degree of control over the transmission of the message, a refusal of jurisdiction when the transmission is incidental to a noncommunication service, and, so far, inclusion of both monopolistic and competitive firms. The elements unique to communications have been preserved as well-namely, at least a rudimentary intelligence content and an exclusion of broadcasters. Yet there have been faults. There has been no clear understanding of the proper theory behind the cable and press association precedents, and there is a general tendency to adopt one rule for a particular technology and to apply it without considering variances in the operation of an in-

the FCC). Communications Act of $1934 \S 201,47$ U.S.C. $\S 201$ (1976), for example, requires common carriers to "establish physical connections with other carriers."

174 See 2 A. KaHN, supra note 47 , at $6,10$.

${ }_{175}$ Id. at 34. See also Competitive Carrier Rulemaking, No. $79-252$ (F.C.C. Jan. 16, 1981) (Fogarty, Comm'r, concurring in part and dissenting in part) (the FCC's proposal "would put the Commission in an analytic straightjacket and would be totally at odds with [the] ... need for flexibility and discretion").

176 Before proposing its more radical form of deregulation, the Commission adopted its proposal in the Competitive Carrier Rulemaking to "deregulate so far as possible" competitive carriers, 77 F.C.C.2d at $310-11$, by presuming market prices to be fair and by eliminating or reducing filing and reporting requirements. 40 Fed. Reg. 76,148 (1980) (to be codified in 47 C.F.R. $\$ \S 61.38, .39, .58,63.07, .71$ ).

177 Indeed, two bills pending in the last Congress would have effected such a revision period. See H.R. 6121, 96th Cong., 2d Sess. (1979); H.R. 3333, 96th Cong., 1st Sess. (1979). 
dividual firm. ${ }^{178}$ In addition, a broader view of the FCC's common carrier jurisprudence reveals a general tendency to look for the quintessential characteristic of common carriage. ${ }^{179}$ This reductive approach fails to recognize that there are several discrete elements in the definition, and that, if the definition is properly applied, the whole is not greater than the sum of its parts.

The Commission has recently proposed the abandonment of its entire body of common carrier precedent. ${ }^{180}$ It views the Act's definition of common carriage as meaningless, and it intends to assert or withhold its Title II jurisdiction solely on the basis of what it perceives to be the policies served by that portion of the Act. ${ }^{181}$ Far from being devoid of content, however, the Act's definition refers to the rich common law of common carriage, and further refines the term for use in the communications context. It is true that the dynamic nature of the telecommunications field produces difficulties in applying the term common carrier, but organization and analysis of FCC common carrier law according to the separate conceptual components of the term should provide a strong theoretical basis for future construction.

Mark A. Hall

178 "Historically, we have ... confined our decisions to the nature of services provided. . . . Thus, once having identified a particular service as a 'common carrier communications' service, we have not previously sought to distinguish among the providers of that service." Competitive Carrier Rulemaking, No. 79-252, I 54 (F.C.C. Jan. 16, 1981).

179 Even where several elements of the definition have been examined in FCC decisions, they have been treated in an imprecise fashion. For example, in its Second Computer Inquiry decision, the Commission presented arguments for treating enhanced communication services as non-common carriage that touched on at least four of the elements discussed here, but did so obliquely without clearly resolving whether absence of any single element was sufficient for its holding. See Second Computer Inquiry, 77 F.C.C.2d 384, 430 (1980) (press association principle); id. at $430,431-32$ (providers of nontraditional services are not common carriers in the "ordinary sense" of the term); id. at 435 (lack of monopoly control); $i d$. (noncommunication elements).

Similarly, the specialized nature of the service offered, the lack of carrier control over the transmission, and the incidental nature of services are all mentioned in Multiple Licensing-Safety \& Special Radio Servs., 24 F.C.C.2d 510, 519 n.2 (1970).

180 Competitive Carrier Rulemaking, No. 79-252 (F.C.C. Jan. 16, 1981).

181 Id. I 54e; see note 23 supra. The Commission relies on an agency's prerogative to construe ambiguous statutory terms, and argues that the best guide for construction is congressional purpose and intent. The flaw in this reasoning is that although the dominant legislative policy should guide the interpretation of a term in cases of true ambiguity, and thus should serve to define its contours, this methodology should not be used to eschew the essential meaning of the term. 